Particulate Composite Materials Technology

THIS DOCUMENT CONFIRMED AS UNCLASSIFIED

DIVISION OF CLASSIFICATION

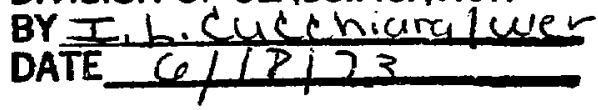

of the University of California LOS ALAMOS, NEW MEXICO 97544

$f$ 
This report was prepared as an account of work sponsored by the United States Government. Neither the United States nor the United States Atomic Energy Commission, nor any of their employees, nor any of their contrac. tors, subcontractors, or their employees, makes any warranty, express or implied, or assumes any legai liability or responsibility for the accuracy, completeness or usefulness of any information, apparatus, product or process disclosed, or represents that its use would not infringe privately owned rights.

Printed in the United States of America. Available from National Technical Information Service

U. S. Department of Commerce 5285 Port Royal Road

Springfield, Virginia 22151

Price: Printed Copy $\$ 0 ;$ Microfiche $\$ 0.95$

$$
\text { Her }
$$


LA-5173

UC-25

ISSUED: May 1973

.

\title{
los Lalamos
}

scientific laboratory

of the University of California

LOS ALAMOS. NEW MEXICO B7544

1 ?

\section{Particulate Composite Materials Technology}

\author{
by
}

R. E. Riley

J. M. Taub

This report was poTICE

sponsored by the prepared as an account of work

the United States nor the United Government. Neither

Commission, nor any of United States Atomic Energy

their contractors, subcontractors, enployees, nor any of

makes any warraty, express or im or their employees,

legal liability or express or implied, or assumes any

pleteness or usefulnessibility for the accuracy, com-

product or lusefulness of any information.

would not infringe privately owned rights. 


\title{
PARTICULATE COMPOSITE MATERIALS TECHNOLOGY
}

\author{
by
}

\author{
R. E. Riley and J. M. Taub
}

\begin{abstract}
Data are presented on various composite materials investigated at the Los Alamos Scientific Laboratory. The significance of powder morphology and the fabrication and final property characteristics of these materials are discussed.
\end{abstract}

\section{INTRODUCTION}

The Los Alamos Scientific Laboratory's (LASL) Materials Technology Group has been involved in the technology of composites for many years. LASL's involvement has included studies on various combinations of elemental and compound materials, and on in situ, laminated, coldpress-sintered, and hot-pressed composites. The optimization of properties has always depended upon the powder characteristics and purity of the raw materials.

\section{IN SITU COMPOSITES}

One of the least understood composites today is the in situ or liquid-phase-sintered composite. Based on our studies on WC-Co and the W-Ni-Fe alloy composite systerns, we have determined that the lack of uniformity and reproducibility of properties in this type material is partly due to variations in powder characteristics and thermal treatments. If the surface chemistry is vastly different for the starting materials, we cannot expect a simple liquidsintering treatment to overcome these differences. B. Kieffer ${ }^{*}$ presented data on the effect of postsolidstate-sintering treatments on the properties of WC-Co alloys. These posttreatments homogenized the matrix alloy giving less data scatter and optimized matrix strength.

LASL's studies on the W-Ni-Fe composite system ${ }^{1}$ have included particlesize effects, liquid-phase-sinter

\footnotetext{
- Paper presented at the Second International Powder Metallurgy Conference held at Stuttgart, Germany, May 1968.
}

times and temperatures, the use of an isothermal hold below the final liquid-phase-sinter temperature, Ni-Fe ratio effects, additives, sintering atmospheres, etc. The matrix phase of this material is subject to hydrogen embrittlement; however, this problem can be minimized or eliminated by cooling the material from $\sim 1200^{\circ} \mathrm{C}$ in an inert atmosphere or vacuum, or by a postvacuum treatment.

LASL's approach has been to investigate the influence of additives on strengthening the matrix phase as well as strengthening and increasing the ductility of the tungsten particles. Of the many additives incestigated, rhenium was the only one that resulted in a marked increase in the strength of the alloy as well as a change in the structure, as shown in Table l. The Ni-Fe ratio and content were held constant and rhenium was substituted for part of the tungsten. The data ${ }^{2}$ show a significant increase in strength that can be attributed to the rhenium. The rhenium also changes the appearance of the microstructure of these alloys, as shown in Fig. 1.

\section{COMPOSITE THERMAL INSULATORS}

\section{Laminat:d Composites}

Laminated composites have received little attention at LASL. However, we recently studied a laminate of $\mathrm{ZrC}$ and Grafoil for use as a high-temperature insulator in a hot-hydrogen environment. The insulating qualities of this material were excellent; however, delamination and leaching of the carbon through the cracks eliminated it as 
TABLE I

PROPERTIES OF RHENIUM CONTAINING W-Fe-Ni ALLOYS

\begin{tabular}{|c|c|c|c|c|c|c|c|}
\hline \multirow{2}{*}{$\begin{array}{l}\text { Sample } \\
\text { Number }\end{array}$} & \multirow{2}{*}{$\begin{array}{c}\text { Rhenium }^{\mathbf{a}} \\
\text { Content } \\
\text { (wt\%) }\end{array}$} & Bull & nsity & \multirow{2}{*}{$\begin{array}{c}\text { Hardness } \\
\text { (DPH) }\end{array}$} & \multirow{2}{*}{$\begin{array}{c}\text { Compressive } \\
0.2 \% \text { Offset } \\
\text { (kpsi) } \\
\end{array}$} & \multirow[t]{2}{*}{$\begin{array}{c}\text { Yield } \\
\text { Strength } \\
\text { 0.5\% Offset } \\
\text { (kpsi) } \\
\end{array}$} & \multirow[t]{2}{*}{$\begin{array}{l}\text { Young's } \\
\text { Modulus } \\
\left(10^{6} \text { psi) }\right. \\
\end{array}$} \\
\hline & & $\left(\mathrm{g} / \mathrm{cm}^{3}\right)$ & (\% Theo) & & & & \\
\hline $0692-6$ & 0 & 18.13 & 99.8 & 320 & 86.0 & 93.6 & 52.4 \\
\hline $0692-9$ & 2 & 18.19 & 100.0 & 345 & 90.0 & 101.8 & 52.4 \\
\hline $0692-8$ & 3 & 18.15 & 99.7 & 365 & 93.9 & 109.6 & 53.0 \\
\hline $0692-10$ & 4 & 18.23 & 100.1 & 390 & 100.0 & 117.5 & 53.0 \\
\hline $0692-1$ & 5 & 18.15 & 99.5 & 385 & 104.0 & 122.7 & 53.4 \\
\hline 0692-11 & 6 & 18.22 & 99.9 & 415 & 110.3 & 129.6 & 52.8 \\
\hline 0692-7 & 7.5 & 18.27 & 100.0 & 435 & 118.7 & 139.0 & 53.6 \\
\hline $0692-2$ & 10.0 & 18.22 & 99.5 & 460 & 132.7 & 154.5 & 52.0 \\
\hline $0692-3$ & 15.0 & 18.29 & 99.5 & 565 & 167.6 & 193.0 & 52.0 \\
\hline $0692-4$ & 20.0 & 1833 & 99.4 & 755 & 219.6 & 247.3 & 52.6 \\
\hline
\end{tabular}

${ }_{A}^{A l l}$ alloys contained 3.5 wt $\% \mathrm{Ni}, 1.5$ wt\% Fe, plus the indicated amount of thenium. The remainder is tungsten.

a candidate for this application. A typical structure showing a delamination crack is shown in Fig. 2.

\section{MC-MO ${ }_{2}$ COMPOSITES}

Another insulator candidate for the hot-hydrogen environment consisted of hot-pressed refractory-metal $M C-\mathrm{MO}_{2}$ composite mixtures. The metal systems investigated included zirconium, niobium, tantalum, hafnium, and uranium. Thermal conductivity measurements at 37 to $50^{\circ} \mathrm{C}$ were the parameters selected to evaluate these materials. The prime candidate system was $\mathrm{ZrC}_{\mathrm{CrO}} \mathrm{Zr}_{2}{ }^{3} \mathrm{~A}$ comparative method involving transient measurements based on standard materials was used in determining the conductivity. The measured values compared with the related values for pure standard samples of the same specimen configuration are presented in Table 1I. The data show that composition had little effect on the thermal conductivity of the $\mathrm{ZrC}_{-} \mathrm{ZrO}_{2}$ composites.

It was therefore decided to investigate the ir.fluence of thermal treatment at 1800,2300 , and $2500^{\circ} \mathrm{C}$ for times up to $16 \mathrm{~h}$ on the thermal conductivity of the 75 vol\% $\mathrm{ZrO}_{2}-25$ vol\% $\mathrm{ZrC}$ composites. The results are summarized in Fig. 3.

The decrease in conductivity with increased time at temperature through $8 \mathrm{~h}$ appears to be a result of chemical change and is associated with ( 1 ) the evidence of formation of monoclinic $\mathrm{ZrO}_{2},(2)$ a decrease in the $\mathrm{ZrC}$ lattice parameter, and (3) a decrease in sample density.
Beyond $8 \mathrm{~h}$ at temperature, the conductivity increascd to about the same level as the as-pressed material. This increase was associated with an increase in densicy and a decrease in the amount of the monoclinic $\mathrm{ZrO}_{2}$ phase present as determined by $x$-ray diffraction.

Metallographic results on the samples treated at $1800^{\circ} \mathrm{C}$ showed evidence of a structural change seen as a white, needle-like precipitate within the $\mathrm{ZrO}_{2}$ grains. There was no evidence of a surface reaction on these samples. The series treated at $2300^{\circ} \mathrm{C}$ showed the formation of a surface reaction that generally increased with increasing exposure time. All samples treated at $2500^{\circ} \mathrm{C}$ showed evidence of melting.

The exact mechanism contributing to the low thermal conductivity of these materials is not known. It has been speculated that one of the constituents responds in a way similar to the effect represented by a void, a phenomenon that has been established. A second theory is based on the fact that alloying takes place at the interface of the oxide and carbide particles resulting in an $M O_{x} C_{y}$ alloy interference zone.

Studies were conducted on $\mathrm{NbC}-\mathrm{ZrO}_{2}$ and $\mathrm{TaC}-\mathrm{ZrO}_{2}$ composites with similar results. While both systems were comparable to the $\mathrm{ZrC}-\mathrm{ZrO}_{2}$ system with respect to insulating characteristics, they have no apparent advantages, and may, conceivably, when heat-treated, oxidize the carbide to form the volatile $\mathrm{Nb}_{2} \mathrm{O}_{5}$ or $\mathrm{Ta}_{2} \mathrm{O}_{3}$, respectively.

The thermal conductivity of a number of other carbide-oxide systems measured at $50^{\circ} \mathrm{C}$ is shown in 


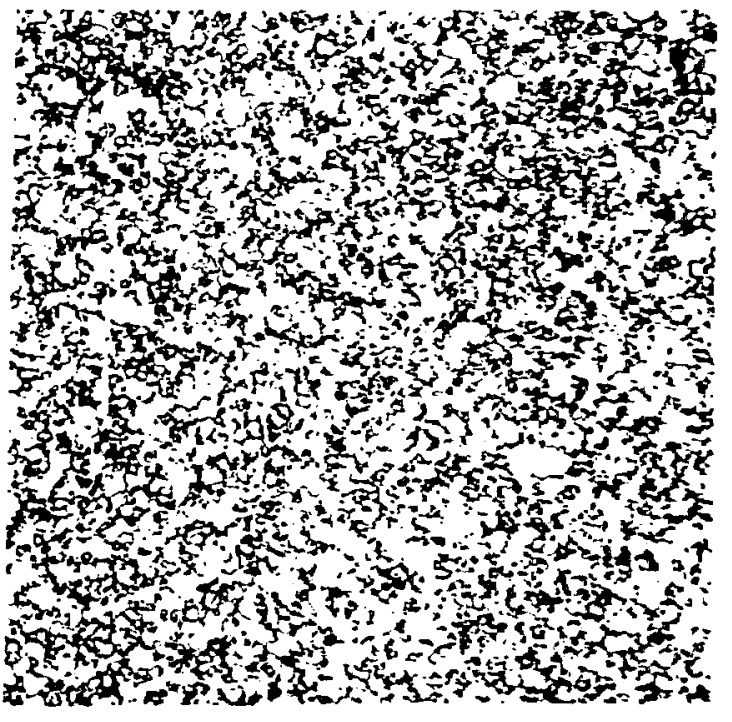

$C \cdot 1520-31(100 X)$.

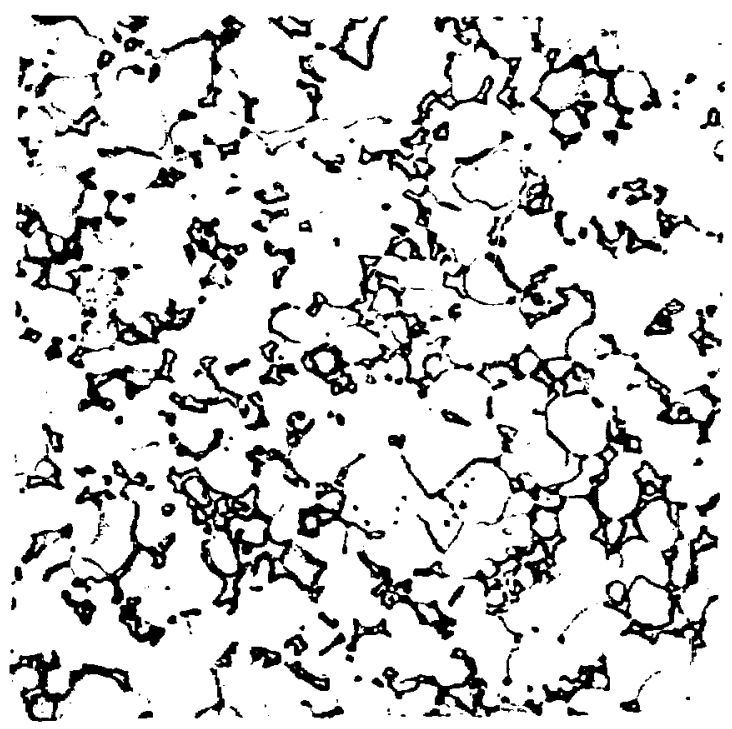

C.1520-31 (500X).

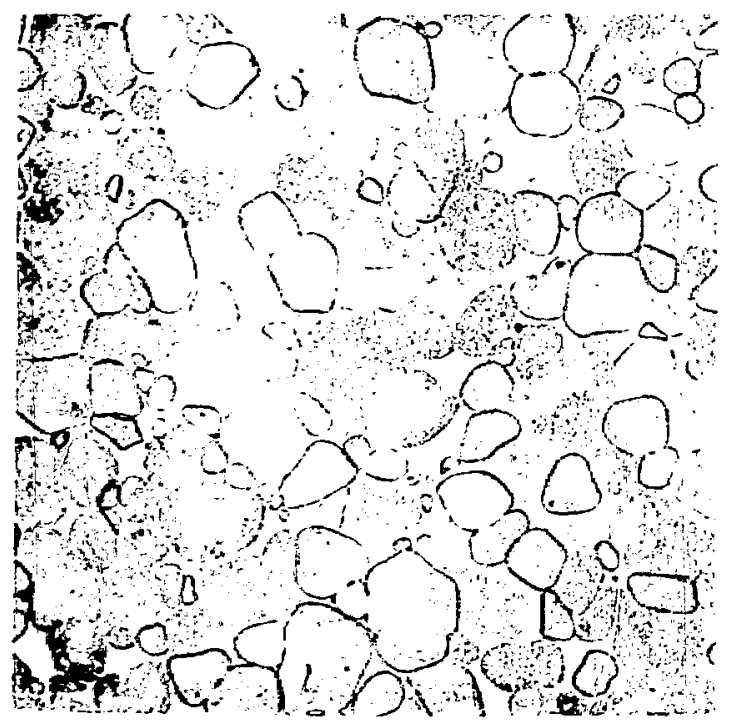

C-1520-34 (100X).

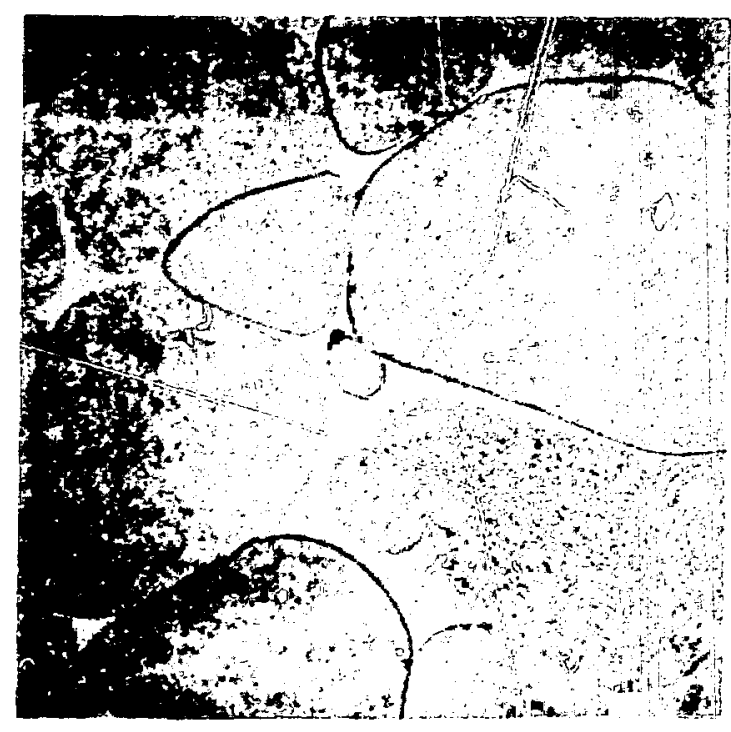

C-1520-34 (500X).

Fig. 1.

Microstructure of W-Ni-Fe alloys with rhenium (left) and without thenium (right). 


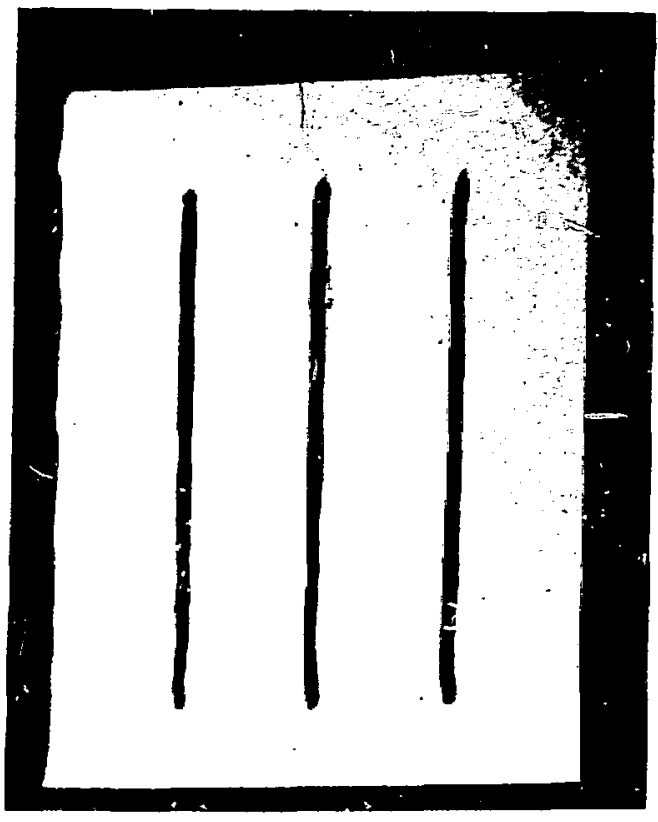

(10X)

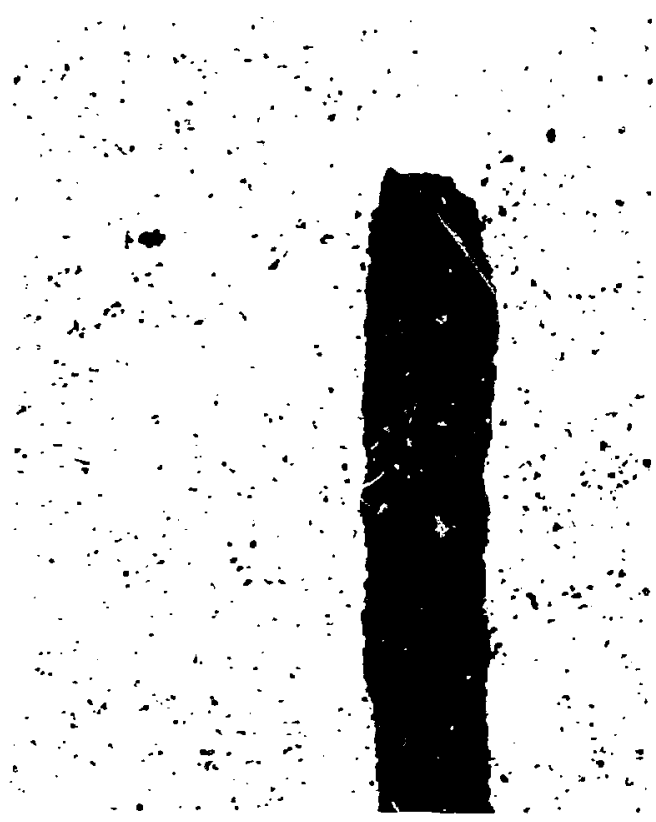

(100X)

Fig. 2.

Cross section of hot-pressed NbC Grafoil washer and structure.

TABLE II

THERMAL CONDUCTIVITY DATA

\section{Composition}

$\mathrm{ZrO}_{2}$

75 vol\% $\mathrm{ZrO}_{2}, 25$ vol\% $\mathrm{ZrC}^{2}$

75 vol\% $\mathrm{ZrO}_{2}, 25$ vol\% $\mathrm{ZrC}^{\mathrm{b}}$

50 vol\% $\mathrm{ZrO}_{2}, 50$ vol\% $\mathrm{ZrC}^{\mathrm{b}}$

25 vol\% $\mathrm{ZrO}_{2}, 75$ vol\% $\mathrm{ZrC}^{\mathrm{b}}$

$\mathrm{ZrC}$

Standards

Lava (fired)

Inconel $\mathbf{7 0 2}$

$\mathrm{Al}_{2} \mathrm{O}_{3}$ (CRS-3)

$\mathrm{BeO}$

${ }^{\mathrm{a}} \mathrm{CaO}$ stabilized $\mathrm{ZrO}_{2}$.

$\mathrm{b}_{\text {Unstabilized }} \mathrm{ZrO}_{2}$.
K

$\frac{c}{\text { Density }} \quad \begin{gathered}\mathrm{K} \\ \left(\mathrm{g} / \mathrm{cm}^{3}\right)\end{gathered} \quad \underline{\left(\% / \mathrm{m}^{\circ} \mathrm{K}\right)}$

1.7

4.970

5.394

5.487

5.362

93.91

90.24

92.60

1.8 to 2.3

1.55

2.6

3.5

27.3

0.98

12.3

31.5

212.0 


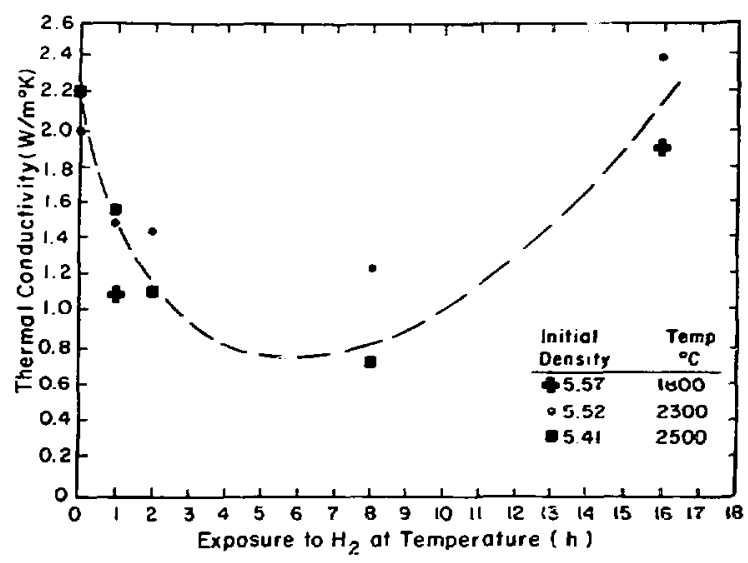

Fig. 3.

Thermal conductivity of 75 vol\% $\mathrm{ZrO}_{2}$ and 25 vol\% $\mathrm{ZrC}$ composires.

TABLE III

\section{THERMAL CONDUCTIVITY OF CERTAIN COMPOSITES AT $50^{\circ} \mathrm{C}$}

\begin{tabular}{|c|c|c|c|}
\hline \multicolumn{2}{|c|}{$\begin{array}{c}\text { Composition } \\
\text { (vol\%) }\end{array}$} & \multirow[t]{2}{*}{$\begin{array}{c}\text { Conductivity } \\
\left(\mathrm{W} / \mathrm{m}^{\circ} \mathrm{K}\right)\end{array}$} & \multirow[t]{2}{*}{$\begin{array}{l}\text { Density } \\
\left(\mathrm{g} / \mathrm{cm}^{3}\right)\end{array}$} \\
\hline $\mathrm{UO}_{2}$ & $\mathrm{ZrC}$ & & \\
\hline$\overline{75}$ & $\overline{25}$ & 3.58 & 7.59 \\
\hline 50 & 50 & 2.97 & 6.70 \\
\hline $\mathrm{UO}_{2}$ & HfC & & \\
\hline 75 & $\overline{25}$ & 2.9 & 8.13 \\
\hline 50 & 50 & 3.0 & 8.60 \\
\hline $\mathrm{HfO}_{2}$ & HfC & & \\
\hline 75 & $\overline{25}$ & 4.10 & 8.14 \\
\hline 50 & 50 & 2.88 & 8.14 \\
\hline
\end{tabular}

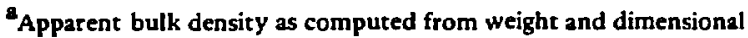
measurements at room temperature. These values are a little below the true density values.

Table III. The data show that these materials are also very good insulators. The data, with respect to the $\mathrm{ZrC}^{-\mathrm{UO}_{2}}$ composite, demonstrate the surprising fact that this mixture has a conductivity lower than that of either pure component at the appropriate density ( $\mathrm{ZrC} \sim 19.0 \mathrm{~W} / \mathrm{m}^{\circ} \mathrm{K}$ and $\mathrm{UO}_{2} \sim 7.0 \mathrm{~W} / \mathrm{m}^{\circ} \mathrm{K}$ ). Most surprising is the fact that an increase in the proportion of the higher conductivity $\mathrm{ZrC}$ phase decreases the conductivity of the mixture. Such a result was totally unexpecied.

In certain very high-temperature applications, a composite insulator must retain its dimensional and structural integrity. No severe structural or dimensional change was encountered until melting was observed. The materials listed in Table IV showed no evidence of degradation or melting after being exposed at the indicated temperature and for the times shown. The $\mathrm{HfC}-\mathrm{HfO}_{2}$ system is of particular interest because of its very hightemperature compatibility.

\section{CARBIDE-GRAPHITE COMPOSITES}

The physical limitations of the more common materials at very high temperatures have led to an exploration of a class of material that might possibly possess some useful characteristics under these extreme conditions. The materials in question are graphite composites, which possess favorable strength properties at high temperatures, and refractory metal carbides. Tanialum carbide has an extremely high melting point, $\sim 3900^{\circ} \mathrm{C}$, and a relatively high TaC-C eutectic temperature of $3710^{\circ} \mathrm{C}$. Nicbium carbide has a meiting point of $\sim 3500^{\circ} \mathrm{C}$ and an NbC-C eutectic temperature of $\sim 3250^{\circ} \mathrm{C}$. Consequently, the intriguing possibility that composites of these hightemperature materials possessed favorable mechanical and physical properties at very high temperatures led to their selection for study. ${ }^{48}$

Two programs were designed to investigate this class of materials in a systematic manner. One program was designed to investigate raw material variables, such as particle size and type, on the material properties of hotpressed composites wherein the process variables were held constant. All composites were based on 46 vol\% TaC-NbC solid-solution carbide content. Five carbon or graphite variations were used and the solid solution was obtained by combining $50 / 50$ wt\% mixtures of the $\mathrm{TaC}$ and $\mathrm{NbC}$ powders.

The second program used this same mixture of carbide and was designed to investigate the effect of composition

TABLE IV

\section{COMPATABILITY TEMPERATURE OF CAREIDE-OXIDE COMPOSITES}

\begin{tabular}{|c|c|c|}
\hline System & $\begin{array}{c}\text { Temperature } \\
\left({ }^{\circ} \mathrm{C}\right)\end{array}$ & $\begin{array}{l}\text { Time } \\
\text { (h) }\end{array}$ \\
\hline $\mathrm{HfC} \cdot \mathrm{HfO}_{2}$ & 2600 & 8 \\
\hline $\mathrm{HfC} \cdot \mathrm{UO}_{2}$ & 2500 & 4 \\
\hline $\mathrm{NbC} \cdot \mathrm{ZrO}_{2}$ & 2300 & 8 \\
\hline $\mathrm{ZrC} \cdot \mathrm{ZrO}_{2}$ & 2300 & 16 \\
\hline
\end{tabular}


on the properties of hot-pressed $\mathrm{TaC}-\mathrm{NbC}$ solid-solution carbide composites wherein the raw material variables and the processing procedures were held constant.

The effect of graphite type and size on the room temperature flexure strength is presented in Fig. 4. The data show that as the particle size of 1008-type graphite flour decreases, there is a significant and accompanying decrease in flexure strength. This, of course, is to be expected because the finer the graphite, the greater the extent of graphite matrix, thus approaching the strength of graphite. Note that the strength is quite high when compared with most commercial graphite. This is because no binder was used and the strength is associated with the extent of the metallurgical bond between the carbide and the graphite particles.

The Varcum flour was made by curing, baking, and graphitizing Varcum-8251 resin, which is a partially polymerized furfuryl alcohol. This material was crushed to a flour and the -325 -mesh fraction was used for this investigation. The average particle size was comparable to that of the -325-mesh 1008 flour. The Varcum flour is not really graphitized, but is basically a glassy carbon that

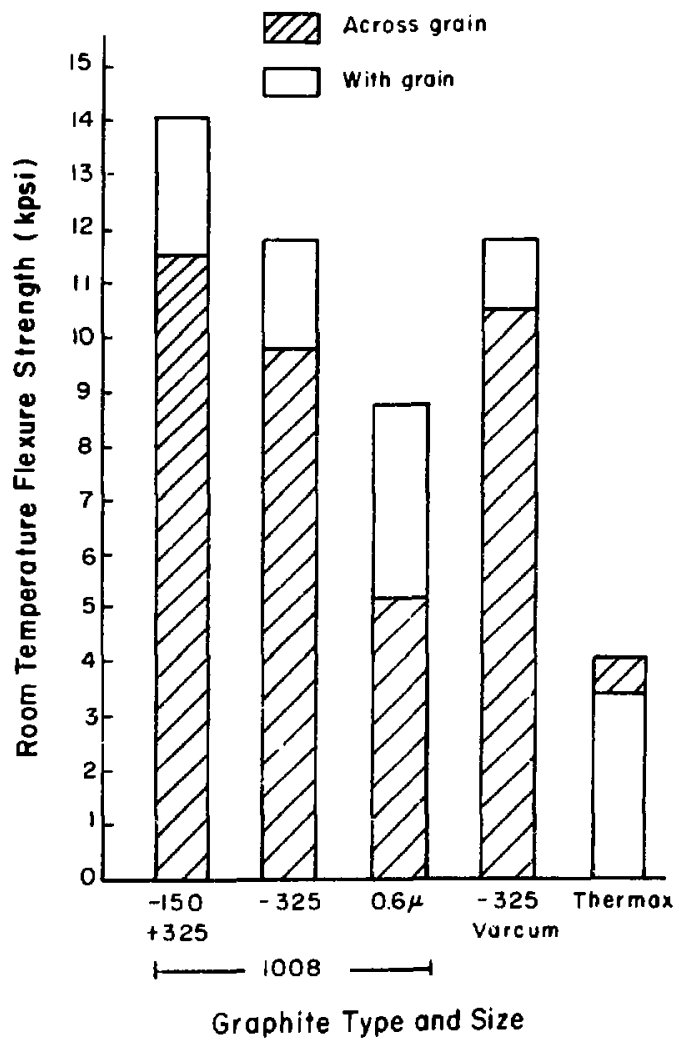

Fig. 4.

Effect of graphite type and particle size on the flexure strength of hot-pressed $39.7 \mathrm{wt} \% \mathrm{TaC}-39.7 \mathrm{wt} \% \mathrm{NbC}-20.6$ wt\% carbon composites. is believed to be partly responsible for its having a highe strength than its counterpart in the 1008 flour. The thermax flour is a very fine, almost spherical carbon blacl and results in very low mechanica! strength. Similar trend and results were observed for room temperature com pressive strength and tensile strength.

Evaluation of potential high-temperature and high power density reactor components requires rapid assess ment of the relative thermal-stress and thermal-shocl capability of candidate materials. Two new experimenta techniques have been developed to meet this requirement Both methods establish temperature gradients in materia samples of simple geometry, essentially flat washers. B) establishing successively higher levels of the temperatur differences, the onset of cracking or fracture can be determined and the relative thermal-stress resistance car be established. One technique is a steady-state (thermal stress) method, wherein an external radiator establishes : temperature difference from the outside to the inside diameter of the washer samples. The second method use: a large radio-frequency power supply to establish a tran sient temperature profile radially in the washer by very rapidly heating (thermal shocking) the outermost rim of the washer samples.

Preliminary results on graphite and metal carbide graphite composite material have established that both methods produce reproducible data and yield similar rankings for the thermal-stress resistance of different materials. Therefore, only the thermal-shock rating is presented in Fig. 5.

With decreasing graphite particle size there is a gradual increase in thermal-shock ranking at crack initiation. The material containing the Varcum flour had the highest ranking due partly to the fact that this flour is a glassy carbon. The thermax had the lowest radiation temperature at crack initiation. This we believe to be due to insufficient carbide to bond this ultrafine carbon black flour.

The effect of composition on thermal-shock ranking is shown in Fig. 6. There is a gradual decrease in thermalshock resistance with increasing carbide content. However, it must be remembered that the graphite type and particle size can also have a significant effect on the thermal-shock resistance as is shown by the spread represented by the vertical line.

The data very dramatically show the influence of composition, wherein the raw materials and processing are held constant. Again, the graphite type and particle size have significant effects, as shown by the spread represented by the vertical line.

ln summary, there is a decrease in strength with decreasing graphite particle size. Although we did not present any physical property data, there is an increase in 


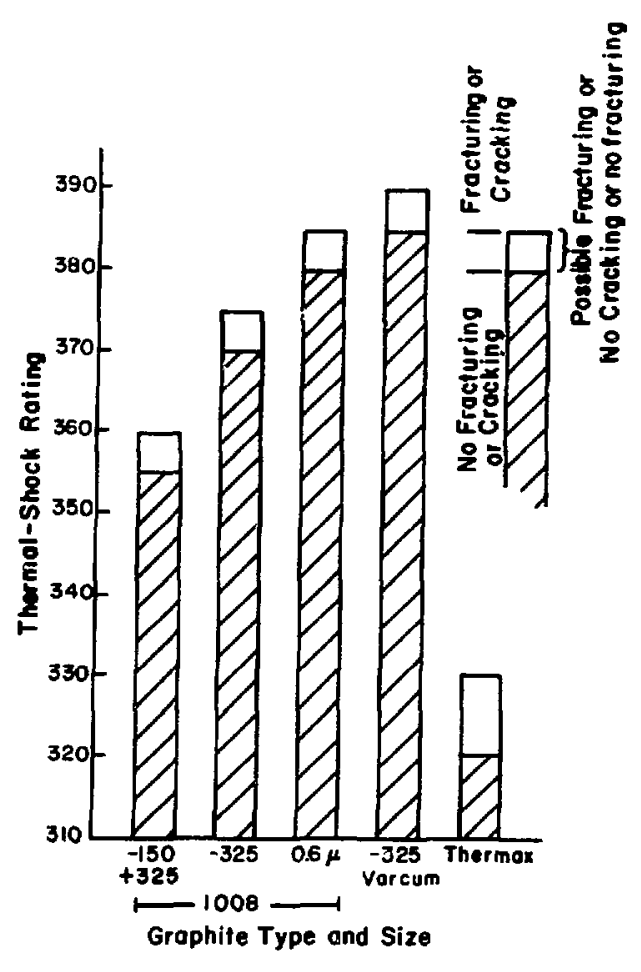

Fig. 5.

Effect of grapbite type and particle size on the thermalshock ranking of bot-pressed $39.7 w t \%$ TaC-39.7 wt\% $\mathrm{NbC}-20.6$ wt\% carbon composites.

electrical resistivity and thermal-stress resistance with decreasing graphite particle size. Thermal expansion appears to be affected little by raw material variations; whereas, dynamic modulus is greatly affected. These factors, plus graphite or carbon type and size, must be considered when trying to tailor a composite toward a particular requirement.

\section{METALBORON COMPOSITES}

In the development of a nuclear rocket engine, $\mathrm{Al}-{ }^{10} \mathrm{~B}$ control plates ${ }^{9}$ were used in the KIWl reactors of LASL's Rover program. This material was difficult to fabricate, expensive, and not readily available. Because of these disadvantages, we had to find a material that would t!iminate any or all of these properties. However, boron is an excellent neutron absorber. Therefore, if a compound consisting of commercial boron could be used, the expensive and complicated separation of the ${ }^{10} \mathrm{~B}$ isotope would be eliminated. In addition to the cost consideration, the material selected must $(1)$ be of the neutron-alpha $(n, \alpha)$

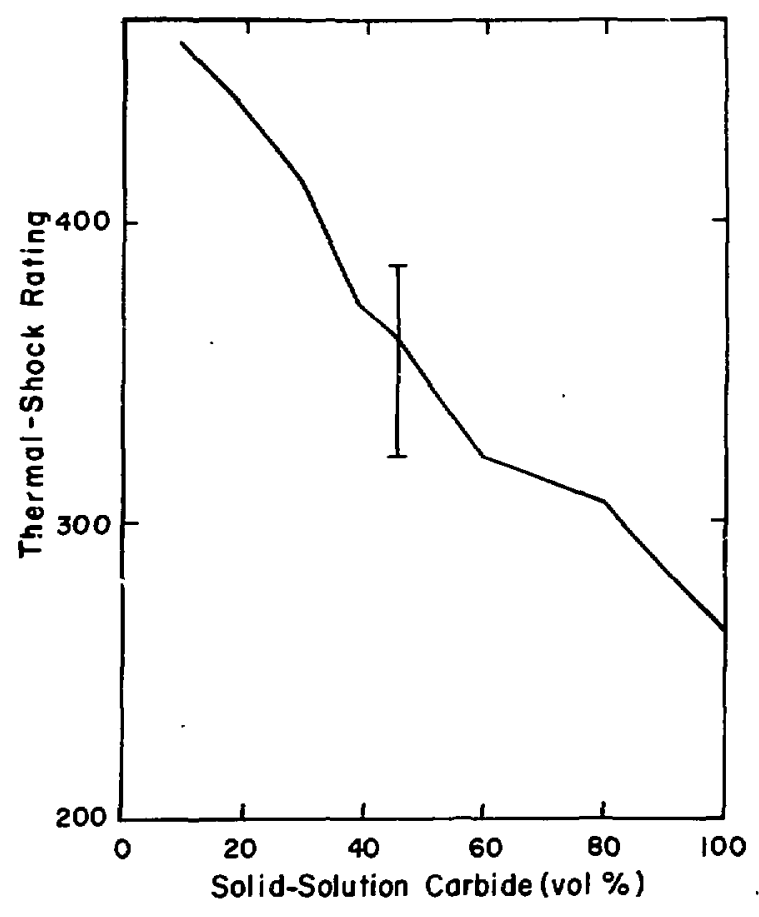

Fig. 6.

Effect of carbide content on the thermal-sbock ranking of bot-pressed carbide grapbite composites. (Carbide consists of a mixture of $50 \mathrm{wt} \% \mathrm{TaC}-50 \mathrm{wt} \% \mathrm{NbC}$.)

type neutron absorber, (2) be dimensionally stable after repeated cycling between 20 and $450^{\circ} \mathrm{K}$, (3) be of sufficient strength and ductility to permit fabrication, and (4) be structurally stable during heating at $800^{\circ} \mathrm{K}$.

Based on these criteria, pure copper was selected as the natrix material ${ }^{10}$ because it does not undergo any phase transformations during thermal cycling, and thus gives dimensional stability. It is also a ductile material and is structurally stable at temperatures above $800^{\circ} \mathrm{K}$. Boron carbide $\left(B_{4} C\right)$ was chosen as the neutron absorber. Although $\mathrm{B}_{4} \mathrm{C}$ is brittle, it is compatible with copper at the temperatures under consideration; and by dispersing the $\mathrm{B}_{\mathbf{4}} \mathrm{C}$ in a copper matrix, the ductility required for the fabrication of the control plates is obtained. Boron carbide has the advantages of being relatively cheap compared to ${ }^{10} \mathrm{~B}$ and being readily available from commercial sources.

A program was established to obtain neutronic data for Cu- $\mathrm{B}_{4} \mathrm{C}$ alloys of varying $\mathrm{B}_{4} \mathrm{C}$ content and to develop a fabrication process for the control plates. The results of these investigations are shown in Fig. 7. The data indicate that $\mathrm{Cu}-21.9 \mathrm{wt} \% \mathrm{~B}_{4} \mathrm{C}$ is essentially the equivalent of the Al-20 wt\% ${ }^{10} \mathrm{~B}$ material used previously. 


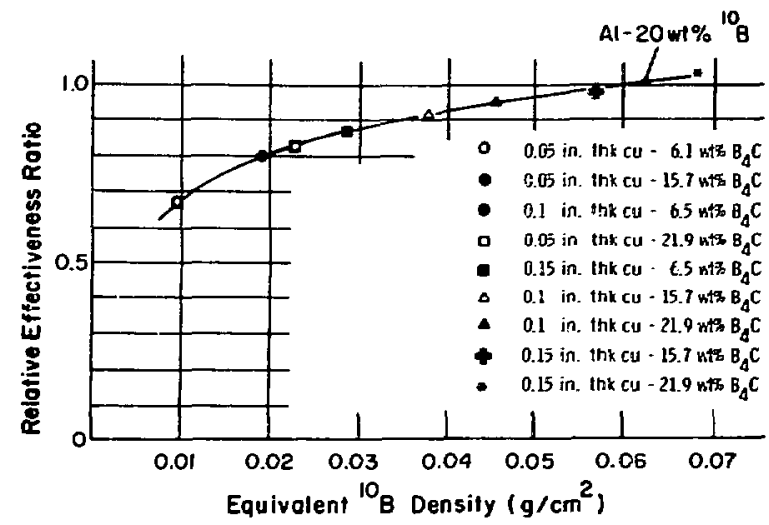

Fig. 7.

Relative neutron effectiveness of $C u-B_{4} C$ sbeet.

\section{MISCELLANEOUS}

Time and space limitations do not permit discussion of the many other composite systems investigated at LASL; however, some of these systems included the development of a norswelling $\mathrm{Mo}-\mathrm{UO}_{2}$ cermet, an improved thermalshock-resistant TaC-Ta chopped-wire composite, and many others. We must emphasize aga in that optimization of any composite system is dependent upon a complete understanding of the particulate characteristics of the raw materials.

\section{ACKNOWLEDGMENTS}

We wish to thank the following LASL people for their contributions to this work: J. T. Frakes and H. Sheinberg for formulation and sintering of the W-Ni-Fe alloys; J.M. Dickinson for the data on W-Ni-Fe-Re alloys; J. Magnuson for the powder characterization data; $\mathrm{N}$. K. Richerson for hot pressing the $\mathrm{MC} \cdot \mathrm{MO}_{2}$ insulators and sintering of the W-Ni-Fe-Re alloys; L. A. Wahman of Group N-1 for the $x$-ray diffraction data; W. Sibbitt of Group N-7 for the thermal-conductivity data; R. Andrae and C. King of Group N-7 for the steady-state thermalstress and thermal-shock data, respectively; B. Barthell and P. Montoya for the hot-pressed carbide-graphite composites; C. E. Peterson, A. Lovato, and T. L. Herrera for the powder preparation, hot pressing, and annealing of the $C u-B_{4} C$ plates and specimens; D.E. Hull and D. E. Carlson of CMB-7 for spheroidizing of the $\mathrm{B}_{4} \mathrm{C}$ particles; R. Keil, L. F. Manker, and E. L. VanDeValde of the CMB-o Fabrication Section for rolling of $\mathrm{Cu}-\mathrm{B}_{4} \mathrm{C}$ plates and blanking of the tensile specimens; and to Groups $M-1$ and $C M B-1$ for the nondestructive inspection and chemical analysis data, respectively; J. D. Orndoff for the neutron absorption data; and T.I. Jones and C. Javorsky for the metallography, tensile, flexure, and bodiness data.

\section{REFERENCES}

1. H. Sheinberg, J. T. Frakes, and R. E. Riley, "Investigation of a High-Density Tungsten-Base Alloy," Los Alamos Scientific Laboratory report LA-4695-MS (October 1971 ).

2. R. E. Riley and J. M. Dickinson, Los Alamos Scientific Laboratory, unpublished data, 1973.

3. R. E. Riley and J. M. Taub, "MC. $M \mathrm{O}_{2}$ Composites: A New Thermal Insulator," Los Alamos Scientific Laboratory report LA-51 36 (February 1973).

4. K. V. Davidson, R. E. Riley, and J. M. Taub, "CarbideGraphite Composites," Los Alamos Scientific Laboratory report LA-3569-MS (October 1966).

5. K. V. Davidson, R. E. Riley, and J. M. Taub, "The Effect of Contaminants on the High-Temperature Properties of Carbide-Graphite Composites," Los Alamos Scientific Laboratory report LA-3618-MS (January 1967).

6. K. V. Davidson, R. E. Riley, and J. M. Taub, "CarbideGraphite Composites - Znd Progress Report," Los Alamos Scientific Laboratory report LA-3652-MS (June 1967).

7. R. E. Riley, "Effect of Graphite Type and Particle Size on the Mechanical, 'hysical, and Thermal-Stress Properties of Carbide-Graphite Composites." Paper presented at Pacific Coast Regional Meeting of the American Ceramic Society, Seattle, Washington, October 16, 1970.

8. R. E. Riley, Los Alamos Scientific Laboratory, unpublished data.

9. R. W. Keil and G. S. Hanks, "Fabrication of Boral Control Plates for KIW1 Reactors," Los Alamos Scientific Laboratory report LA-2737 (August 1962).

10. R. W. Keil, R. E. Riley, and H. Sheinberg, "Feasibility Study for Fabrication of Cu-B ${ }_{4}$ C Sheet," Los Alamos Scientific Laboratory report LA-3570-MS (December 1966). 